\title{
ECO-CONNECTIVITY OF ARTS LEARNING FOR MENTALLY DISABLED CHILDREN AT SLB GEDANGAN SIDOARJO EAST JAVA
}

\author{
Ika Anggun Camelia \\ Universitas Negeri Surabaya, Jawa Timur, Indonesia \\ ikacamelia@unesa.ac.id
}

\begin{abstract}
This study aimed to explore the concept of eco-connectivity appeared in online-based distance learning (PJJ) for mentally disabled children. Furthermore, this study aimed to provide an understand about the need for developing learning models towards the current conventional learning models. Qualitative research with a case study approach was utilized in this study to examine the phenomenon of eco-connectivity of art learning for mentally disabled children at SLB Gedangan Sidoarjo, East Java. The research subjects were IB and AM, the mentally disabled children C at SLB Gedangan Sidoarjo, East Java. This research was conducted from September 2020 to January 2021. The data obtained were analyzed based on John Dewey' point of view about art education and its existence, Cathy Malchiodi about education for children with special needs, and the learning connectivity by George Siemens. The results showed that eco-connectivity maximized teachers' role in adjusting circumstances by designing learning according to essential competencies and making tutorials assisting children's learning with the help of children's learning environments. Ecoconnectivity was also seen in the assessment process by reviewing children's work and interviews with parents. This provided a comprehensive assessment, which further strengthened teachers, parents, and the environment to support mentally disabled children's competence through art learning.
\end{abstract}

Keywords: eco-connectivity, online learning, arts, mentally disabled

\section{EKO-KONEKTIVITAS PEMBELAJARAN SENI ANAK TUNAGRAHITA DI SLB GEDANGAN SIDOARJO JAWA TIMUR}

\begin{abstract}
ABSTRAK
Penelitian ini bertujuan untuk mengeksplorasi konsep eko-konektivitas yang muncul dalam PJJ berbasis daring pada anak tunagrahita. Lebih lanjut, penelitian melakukan pewacanaan terhadap model pembelajaran konvensional untuk memberikan pemahaman perlunya pengembangan model pembelajaran saat ini. Penelitian kualitatif dengan pendekatan studi kasus digunakan dalam penelitian ini untuk mengkaji fenomena eko-konektivitas pembelajaran seni anak tunagrahita di SLB Gedangan Sidoarjo, Jawa Timur. Subjek penelitian adalah IB dan AM, anak tunagrahita C di SLB Gedangan Sidoarjo, Jawa Timur. Penelitian ini berlangsung selama bulan September 2020 hingga Januari 2021. Data yang telah diperoleh dianalisis dengan sudut pandang dari John Dewey tentang pendidikan seni dan eksistensinya, Cathy Malchiodi tentang pendidikan anak berkebutuhan khusus, dan konektivitas pembelajaran dari George Siemens. Hasil penelitian menunjukkan bahwa eko-konektivitas memaksimalkan peran guru menyesuaikan keadaan dengan merancang pembelajaran sesuai kompetensi dasar dan membuat tutorial yang memudahkan pembelajaran anak dengan bantuan lingkungan belajar anak. Eko-konektivitas juga tampak pada proses penilaian, dengan melakukan telaah hasil karya anak dan wawancara dengan orang tua. Hal tersebut memberikan penilaian yang komprehensif, yang semakin menguatkan peran guru, orang tua, dan lingkungan untuk mendukung kompetensi anak tunagrahita melalui pembelajaran seni.
\end{abstract}

Kata Kunci: eko-konektivitas, pembelajaran daring, seni, tunagrahita

\begin{tabular}{|c|c|c|}
\hline Submitted & Accepted & Published \\
\hline 29 Januari 2020 & 10 Maret 2021 & 28 Maret 2021 \\
\hline
\end{tabular}

\begin{tabular}{|l|c|ccccc|}
\hline Citation & $:$ & Camelia, I.A. (2021). Eco-Connectivity of Arts Learning for Mentally Disabled Children at SLB Gedangan Sidoarjo East \\
& & $\begin{array}{l}\text { Java. Jurnal PAJAR (Pendidikan dan Pengajaran), 5(2), } \\
\text { http://dx.doi.org/10.33578/pir.v5i2.8293. }\end{array}$ & 419-430. DOI & $:$ \\
\hline
\end{tabular}

\section{PENDAHULUAN}

Siswa berkebutuhan khusus merupakan anak yang membutuhkan perhatian lebih dalam pembelajaran baik pada kurikulum maupun proses pembelajaran yang spesifik (American
Psychiatric Association, 2013). Adanya permasalahan yang dihadapi oleh anak-anak berkebutuhan khusus yang mengalami hambatan dalam belajar menyebabkan mereka 
membutuhkan layanan pendidikan yang sesuai dengan kondisi masing-masing anak (Pradipta \& Dewantoro, 2019). Oleh karenanya, pembelajaran pada anak berkebutuhan khusus memerlukan strategi agar pembelajaran menjadi optimal.

Salah satu jenis anak berkebutuhan khusus adalah tunagrahita, yang mengacu pada fungsi intelektual umum yang secara keseluruhan berada di bawah rata-rata anak normal yang disertai dengan kekurangan dalam tingkah laku penyesuaian diri yang berlangsung pada masa perkembangannya (American Psychiatric Association, 2013; Penketh, 2016; T. Sampurno, 2015, Desiningrum, 2016). Lebih lanjut, tunagrahita adalah suatu kondisi anak yang kecerdasannya jauh di bawah rata-rata dan ditandai dengan keterbatasan intelegensi dan ketidakcakapan dalam komunikasi sosial. Anak berkebutuhan khusus dengan spesifikasi demikian sering disebut dengan hendaya atau berkurangnya kemampuan dalam segi kekuatan, nilai, kualitas dan kuantitas. Sebagian besar anak tunagrahita mengalami keterlambatan dalam belajar yang sulit jika dikelompokkan dalam sekolah umum.

Tingkat kecerdasan anak tunagrahita diukur melalui tes intelegence quotient atau sering dikena dengan tes IQ. Tunagrahita ringan memiliki rentang IQ 55-70 yang indikasi pembelajarannya hampir sama dengan anak usia 3-4 tahun di bawah usianya, tunagrahita sedang antara IQ 40-55 dengan indikasi pembelajarannya hampir sama dengan anak usia 5-6 tahun di bawah usianya, sedangkan tunagrahita berat memiliki rentang IQ 25-40 indikasi pembelajarannya hampir sama dengan anak usia 6-7 tahun di bawah usianya (American Psychiatric Association, 2013). Pembelajaran disesuaikan dengan tingkat intelegensi anak. Hal tersebut bertujuan untuk memberikan kesamaan dalam kompetensi yang dibutuhkan dalam suatu lingkup pembelajaran. Selain itu, penyesuaian tersebut digunakan untuk mengukur sejauh mana anak tunagrahita berkembang dan dapat ditentukan model kegiatan pembelajaran selanjutnya.

Salah satu pembelajaran bagi anak tunagrahita adalah pembelajaran seni (Penketh,
2016). Berkesenian memberikan efek terapetik, di sisi lain juga mampu meningkatkan kemampuan motorik halus maupun motorik kasar dari anak tunagrahita (M. B. T. Sampurno, Prabandari, et al., 2020). Pembelajaran seni juga sarat unsur kesenangan yang penting dan berkontribusi atas ketercapaian materi yang diajarkan bagi anak tunagrahita.

Desember 2019, muncul virus Corona yang menyebabkan dunia mengalami pandemi yang dikenal sebagai pandemi Covid-19 (Adedoyin \& Soykan, 2020; M. B. T. Sampurno, Kusumandyoko, et al., 2020). Covid-19 menyebabkan terjadinya transformasi model pembelajaran luring ke pembelajaran daring, dalam istilah Pembelajaran Jarak Jauh (PJJ). Hal tersebut terkait dengan kampanye pemerintah dan dunia untuk mencegah penyebaran virus Covid19, yang salah satunya adalah menghindari kerumunan. Oleh karenanya, PJJ seni berbasis daring dianggap menjadi model yang tepat dalam pembelajaran saat pandemi.

Pelaksanaan PJJ mempengaruhi proses pembelajaran seni terutama untuk anak tunagrahita yang memerlukan perhatian lebih untuk memahami setiap materi. Sehingga perlu adanya langkah kolaborasi agar siswa tetap mendapatkan perhatian dalam mengikuti pembelajaran. Lebih lanjut, perlu merancang konsep pembelajaran yang mudah diterima dan sistem penilaian yang dapat dijadikan sebagai bahan evaluasi perbaikan.

Ketercapaian PJJ seni berbasis daring pada anak tunagrahita membutuhkan peran dari guru dan orang tua. Guru merancang materi sesuai kompetensi yang telah ditentukan beserta konsep penyampaian pembelajaran yang sesuai dengan keadaan siswa agar tujuan pembelajaran tercapai. Sedangkan peran orang tua adalah melaksanakan konsep yang telah dirancang oleh guru dengan memberikan pendampingan sesuai instruksi yang diberikan serta memberi penguatan agar siswa dapat memahami pembelajaran (Maxwell et al., 2020).

Berdasarkan penjabaran di atas, penelitian ini mencoba untuk mengeksplorasi konsep eko-konektivitas yang muncul dalam PJJ berbasis daring pada anak tunagrahita. Lebih 
lanjut, penelitian melakukan pewacanaan terhadap model pembelajaran konvensional untuk memberikan pemahaman perlunya pengembangan model pembelajaran saat ini. Penelitian ini bertujuan untuk menemukan model pembelajaran seni berbasis daring atau kelas on line yang mempertimbangkan kebutuhan anak tunagrahita dengan memaksimalkan lingkungan sekitar, peran orang tua serta peran guru, sehingga dapat meningkatkan intelegensi dan memahami materi seperti pengkondisian di kelas off line.

\section{KAJIAN TEORETIS}

Penelitian terkait pembelajaran daring bagi anak tunagrahita masih jarang dilakukan. Hal tersebut didasari atas pencarian tinjauan literatur yang dilakukan secara sistematis (Denzin \& Lincoln, 2013). Pencarian tinjauan literatur secara sistematis dalam penelitian ini mengembangkan strategi pencarian rinci terhadap pangkalan data artikel baik skala nasional maupun internasional yaitu GoogleScholar, neliti.com, ScienceDirect, Taylor \& Francis Online, dan JSTOR. Pencarian dilakukan dengan menggunakan kata kunci yaitu "pendidikan", "pembelajaran seni", "pembelajaran daring", "pembelajaran anak tunagrahita", "pembelajaran seni anak berkebutuhan khusus", dan "pembelajaran saat Covid-19". Setelah ditemukan, artikel diseleksi berdasarkan kesesuaian terhadap penelitian (Gambar 1).

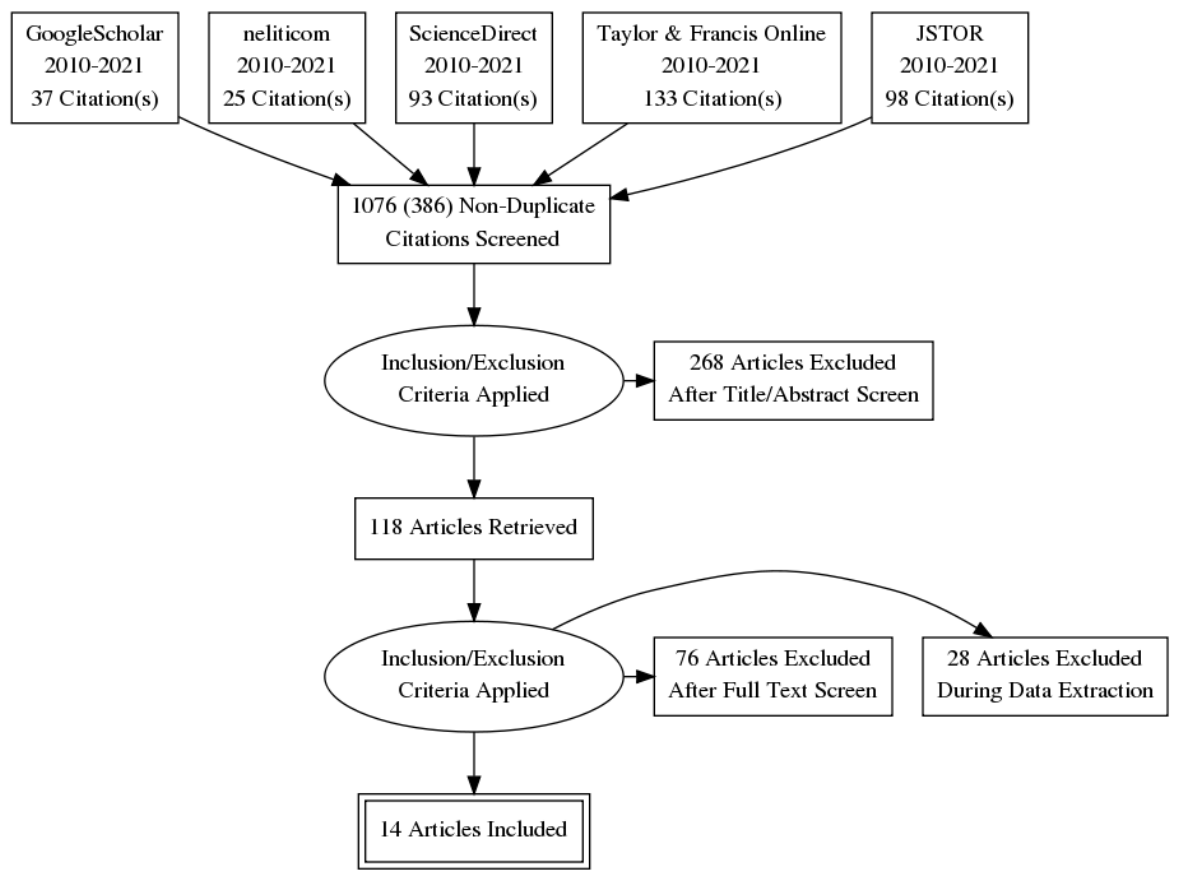

Gambar 1. Alur PRISMA dalam Pencarian Tinjauan Literatur (diadaptasi dari Selçuk, 2019)

Pada penelitian sebelumnya banyak yang membahas perihal proses pembelajaran daring yang dilaksanakan baik disekolah ataupun di kampus (Patton \& Buffington, 2016; Vonderwell $\&$ Zachariah, 2005). Hampir semua proses pembelajaran berjalan lancar namun terdapat keluhan yang hampir sama yaitu mengenai platform yang digunakan seharusnya variatif agar tidak membuat pembelajaran menjadi membosankan (Atina, 2020; Hapsari, 2020; Sadikin \& Hamidah, 2020), namun tetap mempertimbangkan sarana prasarana yang digunakan seperti keterbatasan media komputer dan gawai serta kuota yang akan dikeluarkan oleh 
peserta didik. Untuk kasus di Indonesia, sesuai dengan penelitian oleh Kristina dkk. (2020), aplikasi yang banyak digunakan adalah WhatsApp. Padahal, seharusnya guru mengombinasikan dengan Aplikasi lain untuk menarik minat belajar dan tidak membosankan, serta pemberian tugas seharusnya sesuai jadwal dan juga memperhatikan kuota yang dimiliki peserta didik. Hal tersebut sejalan dengan penelitian yang dilakukan yaitu menelaah bagaimanakah proses pembelajaran daring, namun perbedaannya terdapat pada subjek penelitian yang terfokus pada anak berkebutuhan khusus terutama untuk anak tunagrahita. Lebih lanjut, peran orang tua memiliki andil yang penting dalam proses pembelajaran, meskipun masih dapat dilakukan secara daring, namun orang tua harus menambah waktu untuk mendampingi anak, sedangkan guru harus belajar lebih jauh tentang teknologi, pembelajaran daring dapat dijadikan model pembelajaran selanjutnya (Anugrahana, 2020). Di sisi lain, terdapat pula penelitian yang membahas tentang pembelajaran seni menyenangkan untuk anak berkebutuhan khusus meskipun kuantitasnya lebih sedikit daripada pembelajaran arus utama, perbedaannya terdapat pada proses pembelajaran yang dilakukan secara langsung, sedangkan penelitian ini dilakukan secara daring (Maxwell et al., 2020; M. B. T. Sampurno \& Camelia, 2020). Dapat ditarik kesimpulan bahwa penelitian terdahulu sebagai acuan literatur bagaimanakah proses pembelajaran daring dan karakteristik pembelajaran yang sesuai dengan anak berkebutuhan khusus.

Penelitian ini menggunakan sudut pandang teoretik milik John Dewey tentang pendidikan dan keberadaannya, yang percaya bahwa setiap peserta didik mampu memanfaatkan seni dalam pendidikan selama terdapat kenikmatan di dalamnya (Dewey, 1934, 1938). Hal tersebut didukung oleh interaksi sosial yang mampu memberikan stimulasi sensorik individu yang memungkinkan pemahaman yang lebih tinggi tentang pengalaman individu melalui pendidikan seni (Malchiodi, 2012).

Bagi Dewey, seni berfungsi sebagai pengalaman, proses penelitian, pencarian, dan menemukan makna yang bersifat transformatif, memperluas hubungan dengan pengetahuan kolektif lingkungan dan masyarakat (Dewey, 1938). Hal tersebut didukung oleh pakar pendidikan konektif, yakni George Siemens. Oleh Siemens terkait pembelajaran konektivitas, persepsi yang diperluas membuka tempat untuk pemahaman dan tindakan (Siemens, 2006). Perhatian terhadap detail membangkitkan potensi makna, menghasilkan wawasan masyarakat yang penting, yang sebelumnya diterima begitu saja. Pengalaman transformatif terjadi ketika individu memahami konsep-konsep baru yang terkadang melihat dengan cara yang baru, yang dalam penelitian ini adalah pembelajaran berbasis daring. Hal tersebut memunculkan istilah ekokonektivitas sebagai bentuk siklus koneksi yang interaktif dalam pembelajaran. 'Eko' dalam ekokonektivitas berarti sebuah ekosistem yang saling berinteraksi yang mendukung ketercapaian pembelajaran (Flaherty, 2018; Plummer, 2010; Siemens, 2006; Wang, 2016). Sehingga Ekokonektivitas merujuk pada hubungan persepsi seseorang yang dirangsang melalui pengalaman dengan memahami lingkungan sekitar sebagai salah satu media pengayaan pengetahuan.

Pengalaman dan konektivitas yang selalu menjadi pusat pembelajaran daring, didukung dengan argumentasi Malchiodi yang mengatakan bahwa kedekatan pembelajaran seni bagi individu berkebutuhan khusus dapat memberikan efek terapi (Malchiodi, 2007, 2012). Proses interaksi yang berkelanjutan ketika anak tunagrahita bertindak atas lingkungan dan ditindaklanjuti dilihat sebagai sebuah skema yang edukatif, imajinatif, dan emosional, sehingga memacu untuk mengembangkan pengetahuan selayaknya yang biasa mereka peroleh disekolah secara menyenangkan. Di sisi lain pengalaman mempersepsikan lingkungan akan menambah kepekaan emosional untuk memahami fungsi dan karakkteristik lingkungannya guna memanfaatkan sekaligis melindungi diri dari hal-hal yang mebahayakan.

Malchiodi berpendapat bahwa individu pada dasarnya menyimpan pengalaman reseptif yang mampu terepresentasikan dalam perilaku (Malchiodi, 2007), dan hal tersebut memerlukan pendampingan dan peran serta dari keluarga. 
Ketika pendampingan dilakukan dalam proses pembelajaran, proses seni yang dilakukan akan dinikmati dalam diri anak sendiri dan memberikan pengalaman edukatif yang saling terkoneksi dengan memori serta emosi untuk lebih memeroleh banyak pengalaman atau pengetahuan tentang hal baru (Dewey, 1933, 1934; Malchiodi, 2007). Melalui pendampingan orang tua sebagai kontrol utama dalam pendidikan anak tunagrahita di rumah, mereka memberikan sentuhan interaksi dengan lingkungannya. Perhatian dan pendampingan merupakan kunci utama untuk memacu pemahaman persepsi lingkungan yang dikoneksikan dengan pembelajaran. Pembelajaran daring yang bersifat mandiri kurang dapat terealisasi bagi anak berkebutuhan khusus terutama anak tunagrahita yang notabene perlu perhatian ekstra. Lingkungan merupakan bagian dari kehidupan sehari-hari yang mereka temui sebagai media konektivitas pembelajaran yang bisa dikembangkan melalui bantuan orang-orang terdekatnya.

\section{METODE PENELITIAN}

Penelitian ini menggunakan metode kualitatif dengan pendekatan studi kasus terhadap proses PJJ seni pada anak tunagrahita. Kualitatif dipilih untuk memberikan peluang analisis secara mendalam terhadap pewacanaan eko-konektivitas dalam PJJ seni pada anak tunagrahita (Flick, 2018; Lune \& Berg, 2017). Lebih lanjut, studi kasus dipilih sebagai pendekatan penelitian untuk memberikan penyajian yang detail dan tajam terkait eko-konektivitas yang terjadi, dan konsepkonsep yang ada di dalam proses pembelajaran seni berbasis daring pada anak tunagrahita (Borg \& Gall, 1983; Freeman \& Mathison, 2009; Mertens, 2015).

Penelitian ini dilakukan di Sekolah Luar Biasa (SLB) Negeri Gedangan Sidoarjo, Jawa Timur, dengan subjek penelitian adalah anak tunagrahita $\mathrm{C} 1$ atas nama IB (disamarkan, lakilaki, 10 tahun) dan anak tunagrahita $\mathrm{C}$ atas nama AM (disamarkan, perempuan, 10 tahun). Data diambil dengan metode (1) observasi non partisipatif, di mana peneliti berperan sebagai pengamat yang tidak terlibat secara langsung dalam kegiatan pembelajaran, (2) wawancara, yang dilakukan terhadap Supeni Saputri, yang merupakan guru seni di SLB Negeri Gedangan Sidoarjo, Jawa Timur, (3) dokumentasi dan studi literatur. Penelitian ini berlangsung selama bulan September 2020 hingga Januari 2021. Data yang telah diperoleh selanjutnya akan dianalisis dengan sudut pandang dari John Dewey tentang pendidikan seni, Cathy Malchiodi tentang pendidikan anak berkebutuhan khusus, dan konektivitas pembelajaran dari George Siemens.

Penelitian ini dimulai dari munculnya fenomena perubahan proses pembelajaran yang awalnya tatap muka menjadi pembelajaran daring, selanjutnya peneliti memilih objek dan subjek penelitian yaitu proses pembelajaran jarak jauh di SLB Negeri Gedangan Sidoarjo. Tahap ketiga yaitu mengamati lingkungan dan mengumpulkan data dari hasil wawancara, studi literatur, serta mengumpulkan dokumentasi pendukung (Denzin \& Lincoln, 2013). Setelah semua data terkumpul, dilakukan analisis data kemudian mencocokkan hasil analisis dengan hasil wawancara, studi literatur serta dokumentasi. Tahap akhir menginterpretasi solusi sebagai alternatif penyelesaian dan menulis hasil penelitian

\section{HASIL DAN PEMBAHASAN}

SLB Negeri Gedangan Sidoarjo merupakan salah satu sekolah rujukan untuk anak berkebutuhan khusus di Sidoarjo, Jawa Timur. SLB Negeri Gedangan memberikan layanan pendidikan bagi berbagai jenis kebutuhan khusus seperti slow learner, tunagrahita, autisme, $\mathrm{ADHD}$, tunalaras, tunanetra, tunarungu, tunadaksa, dan tunaganda. Klasterisasi di SLB Negeri Gedangan terdiri dari Sekolah Dasar (SD), Sekolah Menengah Pertama (SMP), dan Sekolah Menengah Atas (SMA). Pembelajaran seni merupakan salah satu mata pelajaran yang diberikan kepada seluruh siswa di SLB Negeri Gedangan Sidoarjo. Namun akibat pandemi Covid-19 pembelajaran seni hanya diberikan kepada siswa SDLB saja dengan menggunakan model PJJ berbasis daring.

Pembelajaran daring pada dasarnya telah populer dimulai pada periode 2010an seiring dengan pesatnya perkembangan teknologi internet (Parrish, 2016). Pembelajaran daring pada anak 
tunagrahita berbeda dari pembelajaran daring pada umumnya. Pembelajaran daring pada anak tunagrahita mengutamakan aspek keberlanjutan yang dominan, lalu dilanjutkan dengan aspek pemahaman dan implementasi serta integrasi terhadap sekitarnya (M. B. T. Sampurno, Prabandari, et al., 2020; T. Sampurno, 2015). Hal tersebut dikarenakan anak tunagrahita memiliki kecenderungan memiliki fokus belajar di bawah anak pada umumnya (T. Sampurno, 2015).

Terdapat konsep pembelajaran yang dipopulerkan oleh John Dewey, yaitu terkait pendidikan melalui seni. Pendidikan melalui seni mengeksplorasi seni sebagai medium atau arena tempat kontemplasi keilmuan terjadi (O'Connor, 2016; Read, 1958). Artinya, seni menjadi media pembelajaran yang mampu mengakomodasi berbagai macam disiplin ilmu. Konsep pembelajaran ini mendukung guru dalam proses pembelajaran pada anak tunagrahita (Penketh, 2016; M. B. T. Sampurno \& Camelia, 2020).

Anak tunagrahita memiliki kelebihan dalam kemampuan motorik (American Psychiatric Association, 2013; Penketh, 2016). Hal tersebut membuatnya memiliki keterampilan dalam melakukan kreasi yang berpusat pada kemampuan motorik. Namun, ketika kemampuan motorik terlalu mendominasi, maka terjadi ketidakseimbangan perkembangan fisiologis, yang menyebabkan tidak maksimalnya materi pembelajaran disalurkan kepada anak (American Psychiatric Association, 2013; T. Sampurno, 2015). Oleh karenanya, dibutuhkan pengaplikasian konsep konektivitas terhadap lingkungan, dan lingkungan yang saling terkoneksi, yang terintegrasi dalam istilah ekokonektivitas (Siemens, 2006).

Eko-konektivitas

merupakan pengembangan dari konsep konektivitas yang dipopulerkan oleh George Siemens (2006). Ekokonektivitas adalah integrasi dari prinsip-prinsip yang dieksplorasi dan berjejaring, serta mengeksplorasi kompleksitas atas teori-teori pengelolaan kelas (Burke, 2020; O'Connor, 2016; Siemens, 2006). Pembelajaran daring dengan konsep eko-konektivitas adalah proses pembelajaran yang terjadi dalam lingkungan daring yang merupakan turunan dari elemen inti pembelajaran seni bagi anak tunagrahita yang mengutamakan konsep bermain dan bersenangsenang (Burke, 2020; Herodotou et al., 2020; M. B. T. Sampurno \& Camelia, 2020), yang sepenuhnya berada di bawah kendali guru dan orang tua sebagai fasilitator pembelajaran. Lebih lanjut, konsep eko-konektivitas memberikan fleksibilitas yang dapat berada di luar pengelolaan pembelajaran arus utama, dan difokuskan pada menghubungkan antar materi, media, kompetensi, dan koneksi yang memungkinkan anak tunagrahita untuk belajar lebih banyak (Burke \& Cleaver, 2019; Herodotou et al., 2020; Siemens, 2006).

Pelaksanaan PJJ seni berbasis daring di SLB N Gedangan mengadaptasi konsep ekokonektivitas yang didorong oleh pemahaman bahwa pembelajaran seni anak tunagrahita didasarkan pada fondasi yang selalu berubah dengan cepat. Eko-konektivitas mendukung dalam penerimaan pengetahuan baru dengan media apapun. Hal tersebut menjadi poin penting, karena dalam kolaborasinya dengan seni sebagai media belajar, maka anak tunagrahita tidak hanya menerima pengetahuan, namun juga mengalami konsep-konsep terapetik (M. B. T. Sampurno, 2019; M. B. T. Sampurno, Prabandari, et al., 2020; T. Sampurno, 2015).

Pelaksanaan PJJ seni berbasis daring di SLB Gedangan Sidoarjo Jawa Timur dikonfirmasi oleh Supeni Saputri sebagai guru mata pelajaran Seni Budaya. Saputri mengatakan bahwa selama pandemi pembelajaran hanya dilakukan dalam satu kelas besar melalui platform Group WhatsApp Messenger sebagai sarana berkomunikasi dengan orang tua atau wali siswa sekaligus memberikan tugas belajar di rumah. Beberapa rangkaian kegiatan pembelajaran yang seharusnya disampaikan oleh pengajar secara langsung harus diwakili oleh orang tua. Hal tersebut dikarenakan anak-anak terutama mereka yang berkebutuhan khusus perlu penjelasan dan pendampingan langsung untuk mendapatkan manfaat lebih jauh tentang pembelajaran yang diperoleh.

Orang tua yang setiap harinya mempercayakan proses pembelajaran kepada guru kini harus menambah perannya, yaitu 
mendampingi putra-putri sebagai wujud guru di rumah dalam pembelajaran mandiri (Burke \& Cleaver, 2019). Awalnya proses pembelajaran dikelas dengan rangkaian pembelajaran yang dimulai dengan pembukaan apersepsi oleh guru dan pengalaman siswa mengenai gambar, menceritakan karakteristik gambar yang akan diwarnai, mengulas tentang bentuk, warna, dan fungsi benda, dilanjutkan dengan pemberian tugas dan pendampingan mewarnai, serta menanamkan karakter baik dalam setiap tahapan penyampaian, yang diakhiri dengan penilaian. Hal tersebut kini menjadi tugas orang tua untuk mendampingi. Hanya saja tahapan pembelajaran tidak mewajibkan orang tua melaksanakan semua seperti tugas guru, hanya mendampingi dan memberikan penjelasan sederhana saja.

Pengalaman dan kerelaan orang tua untuk meluangkan waktu menjadi tombak dalam pembelajaran daring. Permasalahan pertama yang muncul adalah kemauan orang tua menyampaikan konsep gambar yang diberikan. Bila mampu menyampaikan maka permasalahan kedua yang muncul adalah sanggupkah orang tua meluangkan waktu untuk menemani siswa di tengah kesibukan menjalani peran ganda, mengurus rumah atau pekerjaan yang biasanya dilakukan sembari membantu pelaksanaan pembelajaran. Hal tersebut yang mempengaruhi respons orang tua pada platform Group WhatsApp Messenger cenderung berbeda. Terdapat orang tua yang semangat menerima dan mengirim tugas, ada pula yang acuh dan tidak mengikuti perkembangan pembelajaran di group. Sehingga langkah yang diambil oleh Saputri sebagai guru selain memberikan tugas juga memberikan video tutorial dan penjelasan sebagai solusi bila orang tua tidak bisa mendampingi siswa secara maksimal.

Terkait konsep pembelajaran seni di SLB Negeri Gedangan pada dasarnya mengacu pada konsep dasar pendidikan seni, yaitu sarana untuk mengekspresikan apa yang ada dalam diri sebagai bentuk ungkapan rasa hati. Namun selain fungsi tersebut konsep pembelajaran seni yang diterapkan di SLB Negeri Gedangan memiliki konsep yang berbeda setiap jenjangnya. Pembelajaran seni jenjang SD berfungsi untuk mengenal lebih jauh tentang benda-benda yang ada di sekitar, sehingga proses belajar seni didominasi dengan mewarnai benda sesuai dengan apa yang sering dilihat dilingkungan tempat tinggal mereka. Jenjang SMP merupakah peralihan mewarna dan melatih untuk menggambar. Sedangkan untuk jenjang SMA sudah difokuskan untuk menggambar.

Jenjang SD di konsep untuk mengenali lingkungan. Hal tersebut terfokus pada bentuk, warna, dan fungsi atau karakteristik benda. Bila bentuknya seperti daun maka harus diwarna hijau, atau kuning. Bila gambar membentuk air maka diwarna biru, bila membentuk matahari maka diwarna kuning dan oranye. Hal tersebut menjadi dasar pembelajaran dalam mencapai kompetensi mengenali Lingkungan, tentunya penjelasan konsep benda tersebut harus ada pendampingan (Malchiodi, 2007; Read, 1958).

Pada studi kasus yang dilakukan yaitu gambar dua siswa SD yang aktif dalam group WhatsApp Messenger pembelajaran seni yang diampu oleh Supeni Saputri di SLB Negeri Gedangan. Terdiri dari 2 siswa yaitu IB dan AM, IB merupakan seorang tuna grahita $\mathrm{C} 1$ jenis kelamin laki-laki yang berusia 10 tahun dan AM juga Tuna grahita $\mathrm{C}$ berjenis kelamin perempuan yang berusia 10 tahun. Mereka adalah bagian dari kelas harian kecil klaster 1 (tunagrahita) yang terdiri dari 5 siswa. Sedangkan bila masuk ke kelas besar dalam pembelajaran seni terdiri dari 20-25 siswa. 


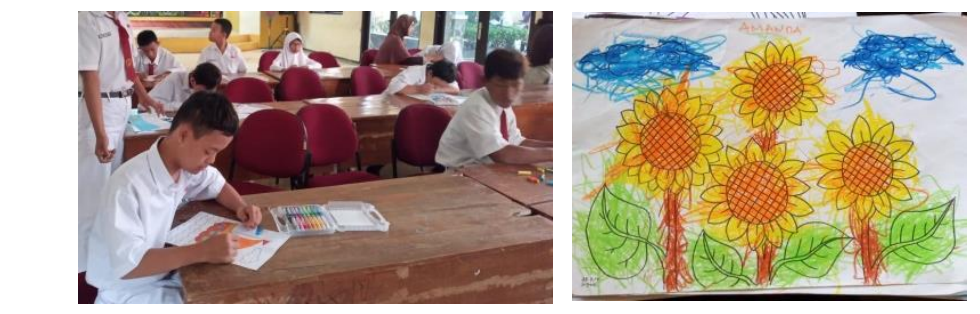

Gambar 2. Karya IB dan AM sebelum pandemi

(Sumber: dokumentasi penulis dengan ijin sekolah, 2020)

Komunikasi merupakan salah satu media untuk saling bertukar pikiran dan berbagi pengalaman, sebelum pembelajaran daring diberlakukan pembelajaran mereka dapat terkontrol dengan baik, namun setelah berubah menjadi pembelajaran daring komunikasi tidak dapat dilakukan secara intensif oleh guru karena Group WhatsApp Messenger berisi orang tua dan guru saja, siswa hanya menunggu instruksi dari orang tua yang sudah membaca tugas guru dari group. Orang tua yang semangat dengan proses pembelajaran daring adalah orang tua dari IB dan AM. Pengerjaan tugas mewarna dikerjakan dengan rentang waktu 1-5 hari sehingga orang tua dapat menyempatkan disela kesibukan sebagai pemeran ganda.

Karakter IB dalam proses pembelajaran masih cenderung lama, karena belum bisa memilih warna sesuai objek sendiri, seringkali salah memilih warna sesuai konsep benda. IB Susah fokus saat mewarna pada setiap tahap. Perlu bimbingan secara terus menerus untuk mendapat hasil maksimal. Kelebihan dari IB dalam menggambar rapi namun prosesnya lambat (Gambar 3).
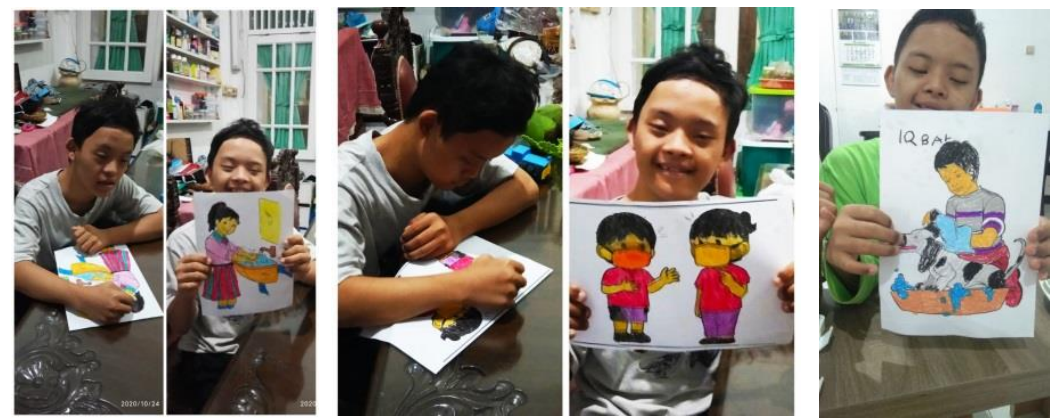

Gambar 3. Karya IB tema protokol kesehatan

(Sumber: dokumentasi penulis dengan ijin sekolah, 2020)

Hasil gambar IB sudah sesuai dengan arahan guru, gambar keseluruhan rapi dan penuh. Tema mencuci tangan dan memakai masker dan menjaga kebersihan hewan merupakan salah satu bentuk pengenalan protokol kesehatan terhadap siswa, sehingga penjelasan lebih lanjut mengenai fungsi cuci tangan memakai masker, dan menjaga kebersihan serta pembiasaan melaksanakannya di rumah merupakan tugas orang tua untuk mengarahkan.

Berbeda dengan IB, karakter AM dalam proses pembelajaran masih cenderung coreng moreng dan kurang rapi, hal tersebut karena pengaruh dari keterbatasannya, namun AM mampu menempatkan warna sesuai bidangnya serta dapat memilih warna untuk dirinya sendiri sesuai pengalaman yang dia lihat (Gambar 4). 

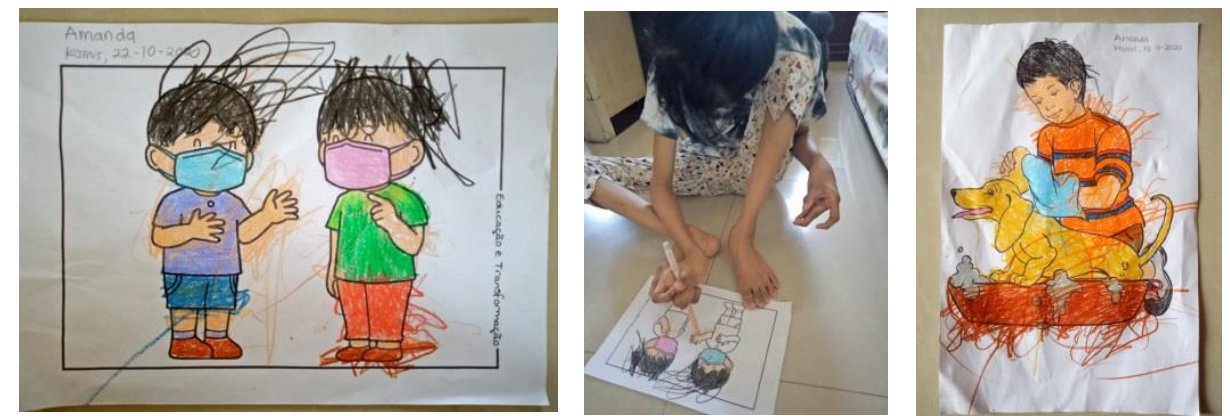

Gambar 4. karya AM tema protokol kesehatan

(Sumber: dokumentasi penulis dengan ijin sekolah, 2020)

Hasil gambar AM sudah sesuai dengan arahan guru. Gambar keseluruhan terkesan coreng moreng namun penempatan dan pemilihan warna yang digoreskan AM sudah sesuai. Memakai masker dan menjaga kebersihan hewan merupakan salah satu bentuk pengenalan dan pencegahan terhadap virus yang berpotensi menyerang semua orang, sehingga orang tua memiliki peran penting mengenai fungsi memakai masker dan menjaga kebersihan serta pembiasaan melaksanakannya di rumah.

$$
\text { Masa pandemi covid-19 banyak }
$$
membatasi ruang gerak pembelajaran, utamanya untuk pengajar sekolah siswa luar biasa yang menjadikan komunikasi dan sentuhan sebagai rangsangan awal proses pembelajaran, yang kini sangat terbatasi dan harus menyesuaikan dengan keadaan. Guru berperan sebagai pemantik yang mengolaborasikan pembelajaran di rumah dengan bantuan orang tua. Kekurangan dalam pembelajaran daring guru tidak dapat melakukan penilaian langsung mengenai perkembangan siswa, sehingga penilaian dilakukan langsung oleh orang tua.

Materi yang diangkat oleh Supeni Saputri pada pembelajaran di SLB Negeri Gedangan dirancang dalam rentang 1 semester, seperti halnya semester ganjil 2020-2021 yang telah dirancang mengangkat tema keseharian dengan pembiasaan baru berhubungan dengan protokol kesehatan. Gambar sengaja dirancang untuk mengenalkan protokol kesehatan, namun tanpa adanya peran orang tua untuk menjelaskan program tersebut maka anak-anak istimewa ini hanya akan belajar mewarna tanpa mengetahui maksud di dalamnya. Cara guru mengetahui perkembangan anak diperoleh dari hasil diskusi dengan orang tua, namun tidak semua merespons diskusi yang dilakukan di group WhatsApp Messenger, sehingga langkah yang dilakukan oleh Supeni Saputri dengan memantau hasil gambar dan mencoba untuk menghubungi orang tua secara pribadi secara bergantian.

Pembelajaran daring yang dilakukan secara kolaboratif dan saling terkoneksi memberikan keniscayaan terhadap implementasi konsep eko-konektivitas (Krasny et al., 2010; Wang, 2016). Siklus tersebut memberikan bantuan penjelas kepada anak tunagrahita sebagai siswa dalam memahami konsep pengetahuan yang tersirat dalam seni yang dibuatnya. Selain itu secara tidak langsung, orang tua bertindak dalam memanajemen ruang kelas dalam rumah. Hal tersebut dilakukan juga dalam lingkup ekokonektivitas dengan mempertimbangkan aspekaspek dan elemen ruang dalam menata benda yang bersifat semi-fix untuk mendukung proses pembelajaran. Oleh karenanya, eko-konektivitas menjadi sebuah keniscayaan dalam proses pembelajaran daring bagi anak tunagrahita selama masa pandemi Covid-19.

\section{SIMPULAN DAN REKOMENDASI}

Pembelajaran seni anak tunagrahita berbasis daring memunculkan kolaborasi orang tua dan pengelolaan lingkungan sekitar untuk 
membantu proses pembelajaran. Hal tersebut mengacu pada konsep eko-konektivitas yang memanfaatkan integrasi dari lingkungan sekitar anak tunagrahita untuk mendukung nuansa akademik berlangsung. Lebih lanjut, ekokonektivitas memaksimalkan peran guru menyesuaikan keadaan dengan merancang pembelajaran sesuai kompetensi dasar dan membuat tutorial yang memudahkan pembelajaran dengan bantuan lingkungan belajar anak.

Peranan guru sebagai pemantik dalam pembelajaran daring adalah merancang pembelajaran sesuai kompetensi dasar yang sudah ditentukan bersama, kemudian dikembangkan dengan pemilihan tema sesuai kondisi dan pembuatan media pembelajaran yang memudahkan siswa untuk memahami pembelajaran sesuai dengan kemampuannya. Cara penilaian dilakukan dengan menelaah hasil karya dan berkomunikasi dengan orang tua siswa. Hal tersebut merupakan representasi dari ekokonektivitas dalam penilaian, dengan dengan melakukan telaah hasil karya anak dan wawancara dengan orang tua. Hal tersebut memberikan penilaian yang komprehensif, yang semakin menguatkan peran guru, orang tua, dan lingkungan untuk mendukung kompetensi anak tunagrahita melalui pembelajaran seni.

Dari penjabaran di atas, diharapkan mampu memberikan gambaran jelas terkait pentingnya peran orang tua dalam konsep pembelajaran eko-konektivitas, terutama dalam pembelajaran daring bagi anak tunagrahita. Perlu disiapkan terkait kompetensi yang harus dipelajari oleh orang tua dalam mendampingi anak belajar di rumah. Di sisi lain, penelitian ini memiliki batasan spasial pada SLB N Gedangan Sidoarjo, Jawa Timur, dan belum melihat pembelajaran seni secara daring dengan kondisi spasial yang lebih luas. Penelitian ini terbatas pada seni, sehingga dalam penelitian selanjutnya diharapkan mampu memperkaya dari sudut pandang spasial yang lebih luas, mata pelajaran yang lebih variatif, dan sudut pandang penelitian yang berbeda. Dukungan terkait data kuantitatif dalam penelitian ini belum mencukupi untuk menjadi sebuah generalisasi penelitian, sehingga dibutuhkan penelitian lebih lanjut dengan pendekatan penelitian berbasis data kuantitatif.

\section{DAFTAR PUSTAKA}

Adedoyin, O. B., \& Soykan, E. (2020). Covid-19 pandemic and online learning: the challenges and opportunities. Interactive Learning Environments, O(0), 1-13. https://doi.org/10.1080/10494820.2020.18 13180

American Psychiatric Association. (2013). Diagnostic and statistical manual of mental disorders (DSM 5) (5th ed.). American Psychiatric Association. https://doi.org/10.1176/appi.books.97808 90425596

Anugrahana, A. (2020). Hambatan, Solusi dan Harapan: Pembelajaran Daring Selama Masa Pandemi Covid-19 Oleh Guru Sekolah Dasar. Scholaria: Jurnal Pendidikan Dan Kebudayaan, 10(3), 282289.

https://doi.org/10.24246/j.js.2020.v10.i3.p 282-289

Atina. (2020). The Effectiveness Of Using Distance Learning Media In The Covid19 Pandemic At SDN 50 Mandau. Jurnal PAJAR (Pendidikan Dan Pengajaran), 4(November), 1324-1333.

Borg, W. R., \& Gall, M. D. (1983). Educational Research: An Introduction (4th Ed.) (4th ed.). Longman.

Burke, K. (2020). "How can the creative arts possibly be taught online?" Perspectives and experiences of online educators in Australian higher education. Asia-Pacific Journal of Teacher Education, 00(00), 115.

https://doi.org/10.1080/1359866X.2020.1 777531

Burke, K., \& Cleaver, D. (2019). The art of home education: an investigation into the impact of context on arts teaching and learning in home education. Cambridge Journal of Education, 49(6), 771-788. https://doi.org/10.1080/0305764X.2019.1 609416 
Denzin, N. K., \& Lincoln, Y. S. (Eds.). (2013). Collecting and Interpreting Qualitative Materials (4th ed.). SAGE Publications.

Desiningrum, D. (2016). Psikologi Anak Berkebutuhan Khusus. Psikosains.

Dewey, J. (1933). How we think. DC Health.

Dewey, J. (1934). Art as experience. Perigee.

Dewey, J. (1938). Experience and education. Collier.

Flaherty, E. (2018). Social-Ecological Resilience: Human Ecology as Theory of the Middle Range. Complexity and Resilience in the Social and Ecological Sciences, 77-145. https://doi.org/10.1057/978-1-137-549785_3

Flick, U. (Ed.). (2018). The SAGE Handbook of Qualitative Data Collection. SAGE Reference.

Freeman, M., \& Mathison, S. (2009). Researching Children's Experiences. The Guilford Press.

Hapsari, S. (2020). The Use of Social Media as an Effective Learning Medium during the Covid-19 Pandemic. Jurnal PAJAR (Pendidikan Dan Pengajaran), 4(November), 1324-1333.

Herodotou, C., Muirhead, D. K., Aristeidou, M., Hole, M. J., Kelley, S., Scanlon, E., \& Duffy, M. (2020). Blended and online learning: a comparative study of virtual microscopy in Higher Education. Interactive Learning Environments, 28(6), 713-728.

https://doi.org/10.1080/10494820.2018.15 52874

Krasny, M. E., Lundholm, C., \& Plummer, R. (2010). Resilience in social-ecological systems: The roles of learning and education. Environmental Education Research, 16(5-6), 463-474. https://doi.org/10.1080/13504622.2010.50 5416

Kristina, M., Sari, R. N., \& Nagara, E. S. (2020). Model Pelaksanaan Pembelajaran Daring pada Masa Pandemi Covid19 di Provinsi Lampung. Jurnal Idaarah, IV(2), 200209.
Lune, H., \& Berg, B. L. (Eds.). (2017). Qualitative Research Methods for the Social Sciences (9th ed.). Pearson.

Malchiodi, C. (2007). The art therapy sourcebook. McGraw-Hill.

Malchiodi, C. (2012). Handbook of Art Therapy. Guilford Press.

Maxwell, N., Doughty, J., Slater, T., Forrester, D., $\&$ Rhodes, K. (2020). Home education for children with additional learning needs-a better choice or the only option? Educational Review, 72(4), 427-442. https://doi.org/10.1080/00131911.2018.15 32955

Mertens, D. M. (2015). Research and Evaluation in Education and Psychology (4th ed.). SAGE Publications.

O'Connor, D. (2016). The golden thread: educator connectivity as a central pillar in the development of creativity through childhood education. An Irish life history study. Education 3-13, 44(6), 671-681. https://doi.org/10.1080/03004279.2014.99 9343

Parrish, M. (2016). Toward transformation: Digital tools for online dance pedagogy. Arts Education Policy Review, 117(3), 168-182.

https://doi.org/10.1080/10632913.2016.11 87974

Patton, R. M., \& Buffington, M. L. (2016). Keeping up with our students: The evolution of technology and standards in art education. Arts Education Policy Review, 117(3), 1-9. https://doi.org/10.1080/10632913.2014.94 4961

Penketh, C. (2016). Special educational needs and art and design education: plural perspectives on exclusion. Journal of Education Policy, 31(4), 432-442. https://doi.org/10.1080/02680939.2015.11 13570

Plummer, R. (2010). Social-ecological resilience and environmental education: Synopsis, application, implications. Environmental Education Research, 16(5-6), 493-509. 
Jurnal PAJAR (Pendidikan dan Pengajaran)

Volume 5 Nomor 2 Maret 2021 | ISSN Cetak : 2580 - 8435 | ISSN Online : 2614 - 1337

DOI : http://dx.doi.org/10.33578/pjr.v5i2.8293

https://doi.org/10.1080/13504622.2010.50 5423

Pradipta, R. F., \& Dewantoro, D. A. (2019). Origami and fine motoric ability of intellectual disability students. International Journal of Innovation, Creativity and Change, 5(5), 531-545.

Read, H. (1958). Education Through Art. Pantheon Books.

Sadikin, A., \& Hamidah, A. (2020). Pembelajaran Daring di Tengah Wabah Covid-19. Biodik, 6(2), 109-119. https://doi.org/10.22437/bio.v6i2.9759

Sampurno, M. B. T. (2019). A Case Study of Therapeutic Process Autistic Children As Performing Art In Indonesia. International Conference on Science, Technology, Education, Arts, Culture and Humanity (STEACH 2018), January 2019, 41-44. https://doi.org/10.2991/steach-18.2019.9

Sampurno, M. B. T., \& Camelia, I. A. (2020). Art and Fun Digital Learning for Children with Special Needs: A Case Study on Applying Art as a Learning Technology. 3rd Social Sciences, Humanities, and Education Conference (SoSHEC 2019), January, 175-180. https://doi.org/10.2991/soshec-19.2019.38

Sampurno, M. B. T., Kusumandyoko, T. C., \& Islam, M. A. (2020). Budaya Media Sosial, Edukasi Masyarakat, dan Pandemi COVID-19. SALAM: Jurnal Sosial Dan Budaya Syar-I, 7(5). https://doi.org/10.15408/sjsbs.v7i5.15210

Sampurno, M. B. T., Prabandari, Y. S., \& Marianto, M. D. (2020). Theoretical Exploration of Art Therapy and Education. International Journal of Indonesian Education and Teaching, 4(2), 260-276.

https://doi.org/10.24071/ijiet.2020.040209

Sampurno, T. (2015). Seni, Melukis, Autisme: Penanganan dan Pengembangan Melalui Seni dan Cara Mengevaluasi Karya Anak Autis. Psikosains.

Selçuk, A. A. (2019). A Guide for Systematic Reviews: PRISMA. Turkish Archives of
Otorhinolaryngology, 57(1), 57-58. https://doi.org/10.5152/tao.2019.4058

Siemens, G. (2006). Knowing Knowledge. Lulu.

Vonderwell, S., \& Zachariah, S. (2005). Factors that influence participation in online learning. Journal of Research on Technology in Education, 38(2), 213-230. https://doi.org/10.1080/15391523.2005.10 782457

Wang, X. (2016). Ecological art education. Anthropologist, 25(1-2), 109-116. https://doi.org/10.1080/09720073.2016.11 892095 